\title{
Point of View, Intertextuality and the Uses of Translation in Lisa Robertson's Early Education
}

\author{
Daniele Borgogni \\ Department of Humanistic Studies, University of Turin, Italy
}

Copyright $\bigcirc 2016$ by authors, all rights reserved. Authors agree that this article remains permanently open access under the terms of the Creative Commons Attribution License 4.0 International License

\begin{abstract}
The paper aims at analyzing from a stylistic perspective how intertextuality and translation practice are employed to build point of view in Lisa Robertson's idiosyncratic text Early Education (2009). Its constant but asystematical mistranslations of Augustine's Confessions, far from being mere linguistic plays, end up being pragmatic modal devices to present the author's stance. This highly original use of translation allows a fruitful stylistic analysis which shows how Robertson's text can challenge and question the Augustinian original and its religious and epistemological tenets, while highlighting its own cultural and ideological bearings.
\end{abstract}

Keywords Robertson, Lisa, Stylistics, Translation, Intertextuality, Point of View, Modality

\section{Introduction}

In this article I would like to propose a stylistic analysis of Early Education, arguably one of the most cryptic texts in Toronto-born writer and scholar Lisa Robertson's 1 collection Lisa Robertson's Magenta Soul Whip (2009). It is a highly idiosyncratic prose poem, a pastiche which repeatedly, but asystematically, mistranslates and misappropriates most of Book I of Augustine's Confessions ${ }^{2}$ to produce a new form of autobiographic narrative. A text which calls attention to its form and its reticent, indirect communication, Early Education yields very interesting results from a stylistic as well as translational perspective, revealing its layers of meaning and implicatures by focusing

1 Lisa Robertson is a writer and university teacher, dealing with such issues as writing techniques, genres, classical culture, and gender. She has produced a crop of varied textual forms from pastoral (XEclogue, 1993) to epic (Debbie: An Epic, 1997), from the style of weather reports (The Weather, 2001) to that of early Italian poets (The Men: A Lyric Book, 2006). In 2005 she won the Pip Gertrude Stein Awards in Innovative Poetry in English and her collection Lisa Robertson's Magenta Soul Whip (2009) was included in The New York Times' Best 100 books.

2 All the quotations from Augustine are from Knöll's editio minor of 1898, readily available online (see for example http://www.augustinus.it/latino/index.htm). on the linguistic expression of point of view as a major stylistic choice in text.

\section{Method}

2.1 Stylistics has always emphasized the importance of point of view ${ }^{3}$, as such groundbreaking works as Leech Short [13] testify. More specifically, the theoretical framework for my analysis will be provided by the Uspensky [26]-Fowler [9 and 10]-Simpson [21] line, in particular the latter's comprehensive model for point of view identification and analysis. However, I will also take up some more recent suggestions, such as Kuno's [12] and Douthwaite's [7] studies, which demonstrated how linguistic categories not directly associated with point of view may function as modalizers in communication. Kuno's "Empathy Perspective" showed how the close interaction between syntactic constructions and discourse perspectives means that an observer never simply reports what he sees. On the contrary, he concurrently evaluates the event, expressing "an attitude toward the participants of the event" through the linguistic choices he has made (315). Douthwaite's study, too, confirmed that modality can be conveyed by a wide array of linguistic elements, thus underscoring the necessity of taking into account a number of functional perspectives that are not contemplated by more rigid discourse approaches but that go a long way towards increasing the methodological tools for the linguistic analysis of communicative strategies. In fact, a sentence may exhibit attitude, opinions, and values without deploying syntactic categories which are defined by the code as carriers of modality. In other words, although commitment and point of view may be realized by grammatical means, they are also context-dependent and sometimes can be understood only if factors in addition to grammar are taken into account. Also

\footnotetext{
3 Point of view is widely used in stylistics, discourse analysis, critical linguistics and translation studies and for this reason in this article it will be preferred to other homologous terms such as "attitude" Halliday [11], "appraisal" Martin [17], "stance" Conrad - Biber [4], or "evaluation" Thompson - Hunston [23].
} 
Semino - Short [20] demonstrated that speech and thought presentation cannot be considered as mere "leftovers" in a linguistic analysis, since a large part of the process of communication is indirect and requires calculating inferences on a concrete text in context, as the relevancetheoretic approach demonstrate (see Sperber - Wilson [22]). The above mentioned approaches are thus important because they treat language use as textual and contextual phenomenon rather than as fundamentally a fact of code. This has also the advantage of avoiding the risk, already signaled by Austin [1], of an easy and mechanical form = meaning equation.

2.2 Early Education develops a very original translational strategy which is tied to what Toolan [25] defines High Emotional Involvement (HEI). The latter is characterized by a special unity of effect and density and represents an epiphanic moment in the narrative which stimulates the reader to pay extra attention. HEI passages are characterized by very specific linguistic features, such as negations, verba sentiendi, syntactic complexity, extreme lexis, temporal deixis, repetitions and parallelisms, borderline grammar structures (see also Toolan [24]), in short by those stylistic aspects which are ascribable to Simpson's pragmatic grammar of point of view. Significantly, however, in Robertson's text HEI passages are also characterized by the repeated recourse to mistranslations, which produce stylistically marked segments dealing with particularly intense, controversial or problematic issues. The misappropriation and dislocation of Augustine's text, then, is a way to underscore the ideological bearing of these textual sections and convey the writer's perspective and attitude. This bears out Lefevere's [14] intuition that any translation is a form of refraction, or an adaptation of a text to a different audience which consequently alters its reception. In Lefevere's words [15], translation is, in fact, "the most obviously recognizable type of rewriting, and potentially the most influential" (9) because it carries an author and/or a text into another culture questioning their status in their culture of origin. If any translation cannot but reflect a certain ideology and what Lefevere [16] called "the Universe of Discourse (i.e. the whole complex of concepts, ideologies, persons, and objects belonging to a particular culture)" (35), the same is even more true in the case of a translation that deliberately distorts and manipulates its original. Thanks to its unconventional stylistic features, then, Robertson's text explicitly bares the ideological practice which is inherently present in any act of translation, and demonstrates that, together with the other, more "canonical" indicators of modality (modal auxiliaries, verba sentiendi, modal adverbs, evaluative adjectives and adverbs and so on), (mis-)translational and intertextual practices, too, are a major way of expressing point of view, although to my knowledge such an approach has not been pursued fully in stylistic analyses.

\section{Results}

As the analysis proposed will try to show, the translation practice which characterizes Robertson's text is an ironical way of deconstructing intertextuality and translation itself as the attempt of "saying almost the same thing" as Eco [8] has it. As a matter of fact, the intertextual dialogue comes under the guise of repeated mistranslations, which indirectly convey the writer's ideological positioning. Early Education, in other words, is not just a game of learned allusions: the constant, but unpredictable, use of Augustine's text means that Robertson's intertextual practice of manipulating that original not only freely adapts and distorts one of the cornerstones of Western culture, but also presents unfaithfulness as an inescapable feature that permeates the text at all levels: she is unfaithful to Augustine' original, since Book I of the Confessions is arbitrarily (mis-)quoted and altered; she is also unfaithful to English, presenting a text which is repeatedly contaminated by Latin, as if English needed to be supplemented with another language in order to achieve proper communication. Even the Latin words and phrases which are maintained in their original form are problematic, totally decontextualized, incoherent and often wrongly quoted, because after all to be coherent is to form enemies (section IV).

Mistranslation, thus, becomes a linguistic practice of choice to stimulate the reader's emotional involvement, but at the same time to show him/her the necessity of achieving an ironical, detached attitude towards the very nature of intertextual and translational practices. The capital letters in silver print which read in the volume's back cover, FIDELITY IS MY OWN DISASTER, summarize Robinson's attempt to stress the ambiguous nature of her text and its mistranslations, but she does not seem to be specifically interested in theoretically discussing such issues as the translator's ethics (on the topic see, among others, Berman [2], Bhabha, [3], Pym [19], Venuti [27]). Rather, the manipulation of Augustine's original is used to stress the necessity of revising inveterate cultural categories and the idea itself of translation and intertextual dialogue. As a consequence, the reader has to face a large number of perplexing passages which repeatedly deconstruct well-established hermeneutic paradigms. Mistranslations, as will be shown in more detail in the following section, come in different guises but are usually based on aural adaptations of the original, in order to stress the ironical displacement they trigger: humanitatem filii, for example, is transformed into feeling humanitatem (section I), while crucis becomes a crutch (section V). In other cases, mistranslations are based on the graphic form of lexemes, so the translational choices are based on the initial sequence of letters of the original, so that, for example, laudare is translated as laughable (section I) and delictorum becomes delicious (section V). Despite their shocking outcome, all these manipulations do not have any blasphemous purpose; rather, they are presented to the reader to underscore the fact that, while texts convey their meanings through their power of expression (see on this the controversial poetics of translating proposed by Meschonnic [18]), communication 
remains highly problematic, if not impossible. Consequently, the reader is invited to be caring and skeptical at the same time, ready to sympathize with the writer's identity struggles but always detached to accept that quomodo item I invoke is unbelievable (section I). Since language is not reliable because it is full of words used past their expiry date (stupid with words past their sweet-arsed date, section VI), it is necessary to make those same words new again through a disloyal translational practice that defamiliarizes them. Robertson's perplexing text, then, opens the stimulating possibility of analysing translation as a different way to account for the opinions and ideological positioning of the writer, although it is presented throughout the text as a risky practice: the ambiguous final sentence with the rescuing of the falling man and the mysterious transformation into a horned animal reinforces the idea of the horned dilemma that writer and readers have to face.

\section{Discussion}

Even on a cursory reading, Robertson's text seems to belong to Fowler's 'Internal type A' category, a predominantly first person mode of narration from the point of view of a participating character who presents her comments and opinions (that is, a foregrounded modality) and frequently recurs to verba sentiendi. The text is an autobiographic meditation in which the narrator discusses her early years and her relationship with an enigmatic dominant. Although it is deeply subjective, the narrative is extremely cryptic and puzzling for the reader, as if the latter should face the same existential doubts discussed in the text. This highly 'subjective' and idiosyncratic mode of narration is evident from the outset:

I designed my own passivity. I present it to you by my face, by your guts, and in the name of human space. I was born into a rough little city, site of hasty invention actively dissolving into steel sky. The city was a glittering ruin sucked upwards.

Graphologically foregrounded by its italic type (on foregrounding see Douthwaite [6]), it features a modality realized chiefly through evaluative adjectives and adverbs (rough little city, hasty invention actively dissolving, steel sky, glittering ruin) which, as Kuno [12] pointed out, cannot be considered as simply reporting or describing, but is concurrently evaluating the event, expressing "an attitude toward the participants of the event" (315).

Moreover, the very first sentence immediately creates a clash between its grammatical and semantic levels: the straightforward actor/process/goal sequence, with its foregrounded first-person actor, is in fact intended to deny that active construction by a goal which is exactly the opposite in meaning (passivity). The same pattern is reproduced shortly after, when a thematized site will be presented in the oxymoronic act of actively dissolving.

As we go on reading, however, it becomes clear that in this particular case the variation in attitude is signaled not only through the selection of which participant to thematize (all the initial sequence thematizes a first-person subject until the last sentence shifts it to the city), but also in the passage from material to relational process (The city was) and from relational to verbalization process (I will relate, let's sing; also invoke clearly entails a verbal process in this case). Significantly, the distortion of the biblical "Who is without sin" reveals the inescapable necessity of verbalization, since everything must be predicated (what is without predicate?).

Section I begins with a long series of relational processes containing generic, apparently universal truths (great virtues are; wisdom has...; the circumference is and so on), which immediately appear incoherent and ironical at the same time: the expectation raised by such a title as Early Education is disappointingly denied by the idea that "wisdom has a laughable magnitude". Moreover, Section I presents a subtle shift as to reference: following Kuno's "Empathy perspective" and the idea that the mode of reference is usually a reliable guide to the addressor's values and opinions, one can notice an ambiguity as to actor naming: usually naming an actor reduces the social and psychological distance between speaker and participant, but in this case the you which recurs in the first part of the text is not attributed any intimacy by the speaker who; on the contrary is all intent to look for, implore and believe in another you, the one in the Latin quotation. As Section 1 develops, in other words, it gives the reader, who might identify with the addressee, the disconcerting feeling that in fact he is just overhearing a more intimate conversation with someone else. At the same time, the text is exposed in its attempt to address a silent, far, mysterious presence who turns out to be a wholly other and makes the speaking voice realize that she is not who she thinks she is, that her activity is in fact a passivity, that fidelity is a disaster.

This feeling of alterity is evoked by the insertion of Latin, which is by no means a sporadic presence. In fact, as it turns out, Robertson's whole is in (never openly acknowledged) dialogue with most of Augustine's Confessions, Book I, as the following synoptic table demonstrates: the underlined terms have been some way or another translated, whereas the bold ones are reproduced in the English text. 
1.1

Magnus es, domine, et laudabilis valde: $\underline{\text { magna virtus tua, et sapientiae }}$ tuae non est numerus. et laudare te vult homo, aliqua portio creaturae tuae, et homo circumferens mortalitem suam, circumferens testimonium peccati sui et testimonium, quia superbis resistis: et tamen laudare te vult homo, aliqua portio creaturae tuae. tu excitas, ut landare te delectet, quia fecisti nos ad te et inquietum est cor nostrum, donec requiescat in te. da mihi, domine, scire et intellegere, utrum sit prius invocare te an laudare te, et scire te prius sit an invocare te. sed quis te invocat nesciens te? aliud enim pro alio potest invocare nesciens. an potius invocaris, ut sciaris? quomodo autem invocabunt, in quem non crediderunt? aut quomodo credent sine praedicante? et laudabunt dominum qui requirunt eum. quaerentes enim inveniunt eum et invenientes laudabunt eum. quaeram te, domine, invocans te, et invocem te credens in te: praedicatus enim es nobis. invocat te, domine, fides mea, quam dedisti mihi, quam inspirasti mihi per humanitatem filii tui, per ministerium praedicatoris tui.
I

great virtues are numerous and wisdom has a laughable magnitude. the circumference of a human creature is his own testimonium, her superb mortal resistance as a creature is a liquid gate. our hearts are intelligible. to excite and to tempt you I will relate the ways of my past unhappiness. should I invoke necessity or fate? quomodo item I invoke is unbelievable. all gods are gravegods. what is without predicate? let's sing to the god who requires it. let's sing to our enemies also. quæram te, invocans te et I'll invent credens in te: a predicate is a noble enemy and my fidelity is my own disaster, inspirasti mihi per feeling humanitatem with this speech.

Figure 1. Synoptic comparison Confessiones 1.1 - Early Education I

In some cases the English text makes a rather intelligible translation (magna virtus > great virtues; numerus > numerous; creaturae...homo $>$ human creature; fides mea $>$ my fidelity; per ministerium praedicatoris $>$ with this speech), but the most numerous and original cases are its usually ironical mistranslations: magnus ... sapientiae... laudare $>$ wisdom ... laughable... magnitude; circumferens $>$ circumference; mortalitatem suam... superbis resistis $>$ her superb mortal resistance; tu excitas... te delectet $>$ to excite and to tempt you; cor nostrum ... intellegere $>$ our hearts are intelligible; invocare nesciens $>$ invoke necessity; sine praedicante $>$ without predicate; laudabunt dominum qui requirunt eum > let's sing to the god who requires it; enim... laudabunt > let's sing to our enemies; invocem > invent; praedicatus enim es nobis $>$ a predicate is a noble; humanitatem filii $>$ feeling humanitatem).

(Mis-)translations are thus a very sly and original way to convey point of view and empathy perspective. In particular, the emergence of a radical alterity is not addressed with a conventional "you" but mediated through the presence of Latin. Among the almost endless examples, two can be singled out for their relevance: Quomodo autem invocabunt, ...non crediderunt becomes quomodo item I invoke is unbelievable. Though obsolete, the term quomodo was used in English, so theoretically Quomodo item is both English and Latin. However, in neither language it makes any sense and this ambiguity, reinforced by the difficult of deciding in what language it is written, illustrates the meaning of the sentence itself: the impossibility of defining the someone (or something?) who is invoked is reinforced by an impossible language. Yet the communication is not blocked; it is simply more indirect, alluded to by the mistranslation, which marks this as a HEI moment in the text.

Also liquid gate deserves mention: it corresponds to the Latin "aliqua portio" but of course it has a completely different meaning than the "small part" of the original text. It is, then, a sort of aural translation, in which portio gets confused with porta and is translated as gate, whereas aliqua is transformed into liquid. Moreover, portio is not exploited in its more obvious homophonic equivalent, portal. This demonstrates that the choice of gate has another rationale, since its association with superb and mortal is rich in implicatures: apart from the "gate of Hell", according to Critchley [5] "The sexual connotations of the female's 'liquid gate' here are telling; and I don't think the Miltonic resonances - from Book III of Paradise Lost - of the 'human creature' and the firmament of heaven: 'an expanse of liquid, pure' accidental."

Section I ends with another short paragraph, graphologically foregrounded in italic type, which is a sort of parallel of the first one (incidentally, they are the only two paragraphs of this kind in the whole text and stand out for their regular syntactic pattern).

(Another version of the same beginning is simpler and more direct: in the long science of submission it is the mind that, quietly spectacular, unhooks the bodies and opens the face.)

It is a long, single sentence which promises to be a clarification (simpler and more direct), but is in fact an extension of the general feeling of ambiguity that permeates the text. The fronting of the long science of submission underscores the semantic concept of submission which had already been advanced in Section I, while the predicated theme in the cleft sentence, mind, is a powerful reminder of the psychological character of a text whose main Hallidayan metafunction is the textual one and which will hardly be able to offer a simpler and more direct version of itself.

Since it would go beyond the scope of an article to include the whole relevant sections of Augustine's, I will limit myself to summarizing the most significant instances of mistranslations as HEI moments.

\section{II}

the dominator is cuddled inside me: what would you call that? when we quibble and feast, what would you call that? since tua quidquid fades, has faded, this quidquid that's your name. all that's feral in me, whatever being I am, eats into my docent. I invoke 


\section{dominance to undo myself.}

I had no enemies, no parent, no clock. dominant you filled the nurse's tits and so abundantly taught me to sip. I'm telling you about things I don't remember, nothing more, fibbing and sipping, sipping and fibbing, very similar. et cum non intellecto me obsessit, non subditus indignation, no servitude. quam scientes is my nutrient.

dominant qui est semper vivus and nothing in us tu creasti et really instabilium et immutable. quam illa intra visceral matrix? dominant my soft word, no memoria could have prepared me for your earth. I am the first suckling among multa, your artifice, your animal, gaudy with cries, gaudy with hunger and lovely with hunger and hunger.

Section II of Early Education is built upon Augustine's 2.2, 6.7, 6.8, and 6.9 paragraphs, with some words also taken from 6.10. There are no references or allusions to the paragraphs between 3.3 and 5.6, so Robertson's text is asystematical but carefully selective in its translational choices. The skipped paragraphs deal with God's presence and pervasiveness in the universe, God's qualities and the reasons why the human soul aspires to Him. Robertson's Section II, on the contrary, presents the figure of the dominator, a free translation of the Latin Dominum, who significantly occupies thematic position and is never given the positive qualities of Augustine's God. The original Latin an quia sine te non esset quidquid est, fit, ut quidquid est capiat te? (2.2) becomes since tua quidquid fades, has faded, this quidquid that's your name. Quidquid, an indefinite neutral pronoun ("anything, whatever"), is the dominator's name, who (which?) is thus a presence without a name, a word which changes into dominant (and it is worth noticing the dizzy refraction of dulcedo mea, Deus meus (6.9) into dominant my soft word). Despite all this, dominant has a clear functional relevance: the relational process in the Latin text (esses in me, 2.2) becomes a material one (eats into my), the transitivity which is usually a prerogative of the narrative voice in an Internal Type A narratives is transferred to the dominant, while ergativity invests the I who, reinstating the idea of submission and passivity, asks to be undone. And, again, this HEI passage features a mistranslation (invoco... ut inde in me veniat deus meus, $2.2>$ I invoke dominant to undo myself): the original's inde is subtly misspelt to become the verb undo, with highly dramatic consequences.

\section{III}

listen to the humans fib. misery dictates. I remember the fibs of my infancy, a fib per heartbeat cooked by earth. will this commemorate me? dominant do you remember me?

my ego's made from milk, abundant fountains of milk, my dominant, my own, which dedicate themselves to the illuminant corpus, instructress of senses, so that I speak to you in the syllables of your name dominant and as bonus I make for you a nest of my ordinary thighs, tu, forma omnia et lege.

ergo dominant for you I have the fidelity of a fox a piglet an enemy a name multum so many fidelities and oblivions for you are shadow and concept with no memory no vestige no need.

\section{IV}

remember the undulant speech of your childhood enemy saying give it give it give it? I give it as various vocables and membranes voluntarily like this I name the liquids and seconds that move the body turning towards memory and emitting sound among its quorum this turning and opening this masking and what gets called humance vitce authors no greater horror.

So who possesses the stamina to parent their own sensibility? no brat does and beneath the school of belts a language its audibility no refuge, no accident. to be coherent is to form enemies. dominant I wanted to wear memory like a moulded hunger willing ahead of myself some form of satisfaction or vindicate legendary torment with what certainty did I console my welts.

V

though dominant even my fibs are ordinary as belts flicking against authority a peccadillo diligently diligently unspeakable.

a kid's weaned on eternal promises and humiliation. dominant give me your superb sign so I can use it as a crutch or a rope cast into my pointless fidelity, yes dominant I'll tell each dilated fib with my dripping tongue as delicious recreation, enstate my credo of necessity, the tongue like an ego to me, dominantwhom shall I serve? without you for whom welts fatten I'd be minus agency minus glory minus number my author who cuddles me insatiably my soul's bulky with you as it is bulky with fibs.

Central sections III, IV and V feature a conspicuous absence of Latin quotations, in sharp contrast with the first two ones, but Augustine's text is clearly present as a subtext to be misquoted and mistranslated. Section III alludes to Augustine's 7.11 and 7.12, the concluding paragraphs on childhood, and establishes a direct link between two terms: just like Augustine's Dominus had become dominant in Robertson's text, so here peccatum is regularly transformed into fib (Exaudi... peccatis hominum ... Et homo dicit haec, et misereris eius (7.11) > listen to the humans fib. misery dictates; me commemorat peccatum infantiae meae (7.11) > I remember the fibs of my infancy; peccato coram... cuius... super terram (7.11) > a fib per heartbeat cooked by earth).

If this translational choice has a clear ideological bearing, even more radical is the aural rendition of the impersonal verb piget (7.12), which is recategorized to become a piglet. 
Once again, translation becomes the weapon for the distortion and appropriation of Augustine's autobiography with the aim of revising its assumptions and presenting a new relationship with the dominant. The same trend is carried on in Section IV, which opens with yet another ironical transformation of Augustine's God: Memini hoc, et unde loqui didiceram $(8.13)>$ remember the undulant speech. The source of knowledge (alluded by its provenance, unde) is recategorized into an evaluative adjective undulant, while the enim (8.13) which recurs in this part of the Confessions, is recategorized into an enemy. Even more radically, the biblical quotation in Augustine's text (auxilium et refugium meum, 9.14, from Psalm 17,3) is rewritten to become no refuge, no accident, and, accordingly, the moment of communion with God that Augustine alludes to in praegrandi affectu tibi cohaerens, estne, inquam (9.15) is turned into to be coherent is to form enemies.

Section $\mathrm{V}$ in a way completes this ideological deconstruction of Augustine's theology: Christ's sacrifice (aeterna promissa nobis per humilitatem Domini Dei, 11.17) becomes the eternal promises and humiliation a kid is weaned on, the pure heart of the faithful (corde casto in fide tua, 11.17) becomes a rope cast into my pointless fidelity with corde mistranslated as rope (probably playing with the Latin chorda) and the evaluative adjective casto is recategorized as a verb. The final undermining of the original's Christian theology is the almost blasphemous aural translation of the vocative Domine Iesu (11.17) into yes dominant.

To sum up, the central sections present a radicalization of the lack of consolation introduced in the first two sections: Augustine's God has been turned into a dominant, a pure, unnamed alterity clearly associated with a violent, ominous presence; all the reference points are lost and the search for coherence means to produce enemies; sin has become a fib (or a peccadillo, in Section V) which one cannot even hope will be forgiven by confession; Jesus is an exclamation. What is striking, however, is that this HEI is evoked indirectly through a meticulous but asystematic translation practice, which freely adapts and distorts one of the cornerstones of Western culture.

VI

whatever the cause of the grace of dogs, the soft odour of books, the quibbling of kids, it's unbearable. no docent knows such grammar. nor am I parsed, me, a vain wreath of milk, vanity itself, caro factum, quia certiones, non spiritus ambulans and islands of written stuff, a vast itinerary of errors as I died upwards towards you, vita mea, like a magnet, sure, like girls die of fierce love and friezes commemorate the fierce cords of light that are their souls and soldiers eat sponge cake and I don't love you and I fornicate towards you singing down down and it is the solemn world I pull against my tummy, down down and no fierce extreme sedates me no sequence of the lips and teeth. say nothing of the soul that flutters its sleeve dictating not this not that not this muddled doctrine. I'll not name each oblivion each venal carthage each dumb rut written up in verse. dominant my ink's not diligent like yours. I simply tug and vend and strum at pacts secundum signa quibbling litteris in commodo. sit poetica stupid with words past their sweet-arsed date.

it is the difficult tally of my tongue to admit that such songs and those of puerile docents stroked my milky ego.

The translations in Section VI seem less arbitrary in their distortion of Augustine's text, in that they follow the original in its attack on written culture. The very first sentence of Augustine's chapter 13, Quid autem erat causae, cur graecas litteras oderam, quibus puerulus imbuebar ne nunc quidem mihi satis exploratum est (13.20) is almost faithfully reproduced in its construction, with the preposed theme in the foregrounded first position, and conveys a similar message, even though graecas becomes the grace of dogs (perhaps a blasphemous inversion of grace of God?), the verb oderam is recategorized as a noun, odour, and the verb imbuebar as an attribute, unbearable. In other cases, Robertson does not use aural mistranslations, but evokes Augustine's attack on Greek and literature through by repeatedly use of negatives: no, nor, non, nothing recur in the section, reinforced by such nouns as vanity, errors, rut, evaluative adjectives such as unbearable, vain, fierce, muddled, venal, dumb, sweet-arsed, difficult, puerile, and verbs such as died, commemorate, fornicate, sedates, tug, vend, strum. Special attention, however, must be devoted to parse: the narrative I is not its actor but its goal, so much so that it undergoes an infinite series of metamorphoses: first it undergoes a grammatical transformation becoming a complement ( $m e$ ), but then it becomes a ludicrous object ( $a$ vain wreath of milk), an abstraction (vanity itself), the core itself of Christian mystery (the elliptical quotation of Verbum caro factum est), until it enters the realm of impossibilities: a non-spirit moving about (non spiritus ambulans), an island of written stuff. This progressive, relentless relativization of everything is icastically conveyed by the tiny misquotation of the original's quia certiores (13.20): in Augustine it alludes to the more solid linguistic studies he made when he was young (the Latin comparative derives from the adjective meaning "certain, sure"), but its solidity as a reference point is completely denied by Robertson's text, which through an apparently insignificant spelling change transforms it into quia certiones, a mistake, an absurd term which, both in Latin and in English, signifies nothing.

\section{VII}

dominant may I call you rex now and feed you tidbits? my heart calls you rex because you're my first part, as rex I'll serve you what are called tidbits and each locution and scribble and number just adores you rex what is vanity is really your 
discipline for vanis peccata delectum multa for the rest of my life to please you I won't fib rex, I promise.

and towards what illusion my little rex do I tighten the cord that is my ink and adulate everything sentient. rex my pet what is suspended between us is sewn of figura.

who can resist a Human? who doesn't finger lies?

The graphological foregrounding of the text (which in fact reproduces Augustine's original) reaches a high point in Section VII, where punctuation is virtually cancelled to produce a torrential sequence of words with no apparent syntactical organization. The initial request of giving dominant the name of rex signals the effort towards a re-approaching with what is now perceived as my first part. The aural mistranslation of the original second person dative pronoun tibi serviat (15.24) into I'll serve you tidbits, however, demonstrates that in fact the role of actor and the material process of calling, regained by the narrative I, mean a domesticating attitude towards what in the previous sections appeared mysterious and frightening. This process of domestication is further confirmed by the fact that rex is invariably a goal in the various processes; the mistranslation of cum vana discerem, tu disciplinam dabas mihi (15.24) as what is vanity is really your discipline even makes it an empty label.

The renewed expressive capacity of the narrative voice is the direct cause of the second paragraph of section VII, which does not find any parallel in the Latin original and with its foregrounded syntax reveals to a now little rex (later rex my pet) the renewed illusion in the power of writing, a metaphorical umbilical cord made of ink linking the subject to any living creature.

Section VII ends with two loaded questions, not full of doubts and anxiety as in Section I and II, but alluding to the regained dignity of human being: who can resist a Human? mistranslates the original's flumen moris humani! Quis resistet tibi? (16.25), which in its turn quotes a reference to God in Psalm 75.8 (incidentally, Human is the only capitalized noun in the text); the second seems to play with the verb finger, possibly meaning touching and cuddling the lies of consciousness but also denouncing them.

\section{VIII}

a word's a precious vase to sip from, an illicit verb. both kids and scholars sip there the sweet lubricity spilling over tongue and rex I sipped also I can safely say this now since I sip from you no other figment no other persona no other sentence rex what is suspended between us

the soldier reaches from behind the falling men's neck to grasp his snout; he is becoming a horned animal.

The opening of Section VIII confirms the metatextual dimension of the text, made of words which, like a vase (again a translation of verba quasi vasa ... pretiosa, 16.26), are full of precious liquids but are fragile at the same time. The absence of punctuation in this last part even allows the possibility that rex is itself a word, a perfect, unmediated instrument of communication from which the narrative I sips from. And if in Section VII there was the perception that what is suspended between us is sewn of figura, now the same sentence is left open and unanswered (even though, once again, it is built as a collage from nouns in Augustine's 17.27: figmentorum ... personae ... sententias).

\section{Conclusions}

The purpose of this article was to analyze how radically translation practice contributes to build point of view in Lisa Robertson's idiosyncratic text Early Education. Its constant but asystematical mistranslations of Augustine's Confessions show a clear communicative value and, far from being a mere linguistic or intertextual play, they are pragmatically employed as modal devices to signal particularly intense moments of the text and to convey the author's ideological stance. Through its highly original and manipulative use of translation, Robertson's text can not only challenge and question the Augustinian original and its religious and epistemological tenets, but demonstrates the hermeneutic potential of translation and its fundamental role in framing the writer's point of view.

\section{REFERENCES}

[1] Austin, J.L., How to Do Things with Words, Oxford: Clarendon Press, 1962.

[2] Berman, Antoine, L'éprouve de l'étranger, Paris: Gallimard, 1984.

[3] Bhabha, H.K., The Location of Culture, London \& New York: Routledge, 1994.

[4] Conrad, Susan - Biber, Douglas, "Adverbial Marking of Stance in Speech and Writing". in Hunston, Susan Thompson, Geoffrey (eds.), Evaluation in Text. Authorial Stance and the Construction of Discourse, Oxford: Oxford University Press, 1999, 56-73.

[5] Critchley, Emily, "Review of Magenta Soul Whip", in HOW2 III, 3 (2009), www.asu.edu/pipercwcenter/how2journal/vol 3_no_3/review/critchley.html, last accessed 7th January 2016 .

[6] Douthwaite, John, Towards a Linguistic Theory of Foregrounding, Alessandria: Edizioni dell'Orso, 2000.

[7] Douthwaite, John, "A Stylistic View of Modality", in Garzone, Giuliana - Salvi, Rita (eds.), Linguistica, linguaggi specialistici, didattica delle lingue: studi in onore di Leo Schena, CISU: Roma, 2007, 107-156.

[8] Eco, Umberto, Dire quasi la stessa cosa, Milano: Bompiani, 2003. 
[9] Fowler, Roger (ed.), Essays on Style and Language, London, Routledge \& Kegan Paul, 1966.

[10] Fowler, Roger, Linguistic Criticism, Oxford: Oxford University Press, 1986.

[11] Halliday, M.A.K., Explorations in the Functions of Language, London: Arnold, 1973.

[12] Kuno, Susumu, "Empathy and Direct Discourse Perspectives". in Horn, Laurence - Ward, Gregory (eds.), The Handbook of Pragmatics, Oxford: Blackwell, 2004, 315-343.

[13] Leech, Geoffrey - Short, Mick, Style in Fiction. A Linguistic Introduction to English Fictional Prose, London: Longman, 1981.

[14] Lefevere, André, "Mother Courage's Cucumbers: Text, System and Refraction in a Theory of Literature", Modern Language Studies 12, n. 4 (1982), 3-20.

[15] Lefevere, André, Translation, Rewriting and the Manipulation of Literary Fame, London: Routledge, 1992.

[16] Lefevere, André (ed.), Translation/History/Culture: A Sourcebook, London: Routledge, 1992.

[17] Martin, J.R., "Beyond Exchange: Appraisal. Systems in English". in Hunston, Susan - Thompson, Geoffrey (eds.), Evaluation in Text. Authorial Stance and the Construction of Discourse, Oxford: Oxford University Press, 1999, 142-175.

[18] Meschonnic, Henri, Poétique du traduire, Verdier: Lagrasse, 1999.
[19] Pym, Anthony, On Translator Ethics, Amsterdam: John Benjamins Publishing, 2012.

[20] Semino, Elena - Short, Mick, Corpus Stylistics: Speech, Writing and Thought Presentation in a Corpus of English Writing. London: Routledge, 2004.

[21] Simpson, Paul, Language, Ideology and Point of View. London: Routledge, 1993.

[22] Sperber, Dan - Wilson, Deirdre, Relevance. Communication and Cognition. Second Edition, Oxford: Blackwell, 1995.

[23] Thompson, Geoffrey - Hunston, Susan, "Evaluation: An Introduction", in Hunston, Susan - Thompson, Geoffrey (eds.), Evaluation in Text. Authorial Stance and the Construction of Discourse, Oxford: Oxford University Press, 1999, 1-27.

[24] Toolan, Michael, Narrative Progression in the Short Story. A Corpus Stylistic Approach, Amsterdam-Philadelphia: John Benjamins, 2009.

[25] Toolan, Michael, "Is Style in Short Fiction Different from Style in Long Fiction?", Études de Stylistique Anglaise IV (2013), 95-105.

[26] Uspensky, Boris, A Poetics of Composition: The Structure of the Artistic Text and Typology of a Compositional Form, Berkeley: University of California Press, 1973.

[27] Venuti, Lawrence, The Translator's Invisibility, London, \& New York: Routledge, 1995. 